\title{
National Policy Prospects on China One Belt-One Road (OBOR) Initiative Towards Indonesia as Global Maritime Nexus
}

\author{
Riko Ratna Setiawan, Muhammad Kamil
}

riko.ratset97@gmail.com,kamil@umm.ac.id

1Departement of Governmental Science, University of Muhammadiyah Malang

2 Departement of Governmental Science, University of Muhammadiyah Malang DOI https://doi.org/10.22219/sospol.v7i1.15141

\begin{abstract}
This study aims to see how the prospects of national policy regarding the regulation of the One Belt-One Road Initiative (OBOR), which is a mega project that is still being discussed in the world. The project initiated by the Chinese state invites cooperation with various countries in the world in order to reactivate the maritime silk route, including Indonesia. There are 5 pillars of OBOR which are strengthening connectivity, improving infrastructure, promoting trade and scurity, increasing monetary circulation and increasing public understanding of maritime cooperation. There are some indonesian political experts argue that this cooperation will be dominated by China in all five pillars, which in the end will only make Indonesia "an instrument", not an actor. This is what the authors will discuss in this research. The purpose of this research is to see how the national policy prospects on OBOR regulations. This research is analyzed using descriptive qualitative methods by taking data from various relevant sources to the discussion topic. This article results in the finding that What Indonesia needs to do is always provide escort to Indonesia's national interests in the OBOR project. Indonesia must always refer to the five pillars of the World Maritime Nexus, in order to provide absolute benefits for Indonesia.
\end{abstract}

\begin{abstract}
Abstrak
Penelitian ini bertujuan untuk melihat bagaimana prospek kebijakan nasional terhadap regulasi One Belt-One Road Initiative (OBOR), yang merupakan mega proyek yang masih menjadi bahasan didunia. Proyek yang diprakarsai oleh negara Tiongkok ini mengajak kerjasama dengan berbagai negara yang ada didunia dalam rangka ingin mengaktifkan kembali jalur sutra maritime, tak terkecuali Indonesia. Terdapat 5 pilar utama dalam kerja sama OBOR yaitu, memperkuat konektivitas, meningkatkan infrastruktur, promosi perdagangan, peningkatan sirkulasi moneter dan meningkatkan pemahaman masyarakat seputar kerja sama maritim. Terdapat beberapa ahli politik dalam negeri yang berpendapat bahwa kerja sama ini akan didominasi oleh Tiongkok dalam kelima pilar tersebut, yang pada akhirnya hanya akan menjadikan Indonesia sebagai “alat”, bukan aktor. Hal inilah yang lantas akan penulis bahas dalam penelitian ini. Penelitian ini dianalisis menggunakan metode kualitatif deskriptif dengan mengambil data dari berbagai sumber yang relevan dengan topik pembahasan. Artikel ini menghasilkan temuan bahwa Indonesia perlu memberikan pengawalan secara rutin terhadap kepentingan nasional Indonesia dalam proyek OBOR, dimana Indonesia harus selalu mengacu pada lima pilar Perhubungan Maritim Dunia, agar dapat memberikan manfaat mutlak bagi Indonesia.
\end{abstract}

\section{Keywords \\ One Belt One Road, Global \\ Maritime Nexus, National Policy \\ Prospects, Initiative, Indonesia- \\ China's Coorperation}

\section{Article History}

Received January 8, 2021

Revised February 6, 2021

Accepted March 24, 2021

Published April 15, 2021

\section{Corresponding Author \\ Muhammad Kamil, Perum \\ Griya Permata Alam Blok El- \\ 19, Ngijo, Karangploso, \\ Malang, 65152}

\section{Introduction}

Indonesia has agreed to join the OBOR, a coorporation project initiated by China. This project has five main pillars which are strengthening connectivity, improving infrastructure, promoting trade and security, increasing monetary circulation and increasing public understanding 
of maritime cooperation. This cooperation is a form of continuity between the two countries which has existed for more than half a century. In this cooperation, the two actors have different strengths which are expected to be able to contribute to the five pillars of OBOR. China which has a land area of 9,634,057 km2 and water of 4.7 million $\mathrm{km} 2$. Bordered by 14 countries by land and next to eight countries at sea, China is the third largest country in the world with the largest population in the world. At the end of 2016, China had a population of around 1.3 billion. It is the second largest economy and is one of the fastest growing economies in the world. Meanwhile, Indonesia is the largest archipelago in the world, consisting of 35 provinces and 260 million people. The country is located in Southeast Asia in a strategic position between the Indian Ocean and the Pacific Ocean and flanked by two broad continents. Indonesia is one of many developing countries with a stable economy, averaging 5\% annual economic growth (Lovina et al., 2014).

Since first serving as president of China, Xi Jinping has issued ambitious programs, which is the Belt and Road Initiavie (BRI) or also called the One Belt-One Road (OBOR) was launched in 2013 which connects the Eurasian economy with infrastructure, trade, and also investment. BRI itself has 2 main components, namely the Silk Road Economc Belt and the 21st Century Maritime Silk Road. The Silk Road Economic Belt is a land route with the aim of connecting the western provinces of China with Europe through Central Asia. Whereas the 21st Century Maritime Silk Road as a sea route aims to connect China's rich coastal provinces with Southeast Asia to Africa through ports and railways (Cai, 2017). With a path that can connect China with several countries in various parts of the world, this will increasingly make it easier for China to move the wheels of its economy.

OBOR is a big project, where this project will cross 3 continents, namely Asia, Europe and Africa and $3 / 4$ energy sources with a target of 4.4 billion population in 67 countries so that it can represent $63 \%$ of the total global population (Mwatela \& Changfeng, 2016). With more than 60 partner countries joining OBOR, the silk route is implemented through bilateral and multilateral mechanisms between China and these partner countries to achieve common interests (Lovina et al., 2017) In this case, China does need a large amount of funds so that BRI can be realized in accordance with expectations. The expenditure required by China annually to finance this project is approximately $\$ 100$ billion per year. With this huge cost, China finally established the Infrastructure Investment Bank in 2013 and the Asian Infrastructure Investment Bank in 2014 and also the Silk Road Fund in 2015.

Since it was formalized in 2013, OBOR has become China's national strategy in launching the wheels of its economy, which part of its grand plan to rejuvenate the Ancient Silk Road or the tradistional East-West trading corridor. The concept of "One Belt-One Road" is actually a combination of two initiatives the Silk Road Economic Belt (SERB) and Twenty-First-Century Maritime Silk Road (MSR) (Singh, 2016). At first, the initiation of OBOR was understood by the Chinese Ministry of Commerce as an export solution for the steel manufacturing sector in western China, but later succeeded in becoming China's foreign policy to create economic corridors by integrating the geopolitical and geoeconomic forces of middle power countries in Europe, Asia, and Africa, with China at its center (Sari, 2017). With the existence of OBOR being made as a policy made by China, OBOR is developing more broadly which not only focuses on the economic sector of trade, but also development cooperation that exists on land and sea. 
China gives several priorities when initiating OBOR. The first is to have to coordinate all economic development strategies and policies from each region passed by OBOR by developing a measurable and integrated cooperation plan in one joint regulation. Second, improving global connectivity through the construction of an integrated infrastructure network within a framework of work systems with the same technical standards. Next is expanding the investment land by providing trade-free facilities. All these priorities are expected to be able to form a conducive economic environment for China and the countries that OBOR will pass (Yunling, 2015).

Asia is lately fortunate. The Asian Quartet (China, India, Indonesia and Japan) has lately received worldwide attention on account of the coming to power of new "Clear-Eyed" apex leaders, who are pushing for growth-oriented policies and ,utual prespority, thereby imoarting momentum to Asia's "Rise" (Khurana, 2015). Indonesia is a country that has potential in terms of marine economy which is a source of prosperity for the community. Indonesia, which is the largest archipelago country, has maritime potential in various fields that are not only biotechnology and marine tourism, deep sea waters and marine minerals, but also the shipping industry and also the defense and maritime industries. Besides that, the potential of these natural resources, Indonesia also benefited from strategic strategic political and economic territorial locations. Indonesia is located in the equatorial region, between the continents of Asia and Australia which directly connects the economies of developed countries. In addition, Indonesia is also located between two oceans, namely the Pacific and the Indies, which makes Indonesia a connecting region between countries in East and Southeast Asia and South Asia. Some strategic straits of global maritime traffic are also in Indonesian waters, namely the Malacca Strait, the Sunda Strait, the Lombok Strait and the Makassar Strait (Chen, 2015).

In the East Asia Summit held on November 13, 2014, the President of the Republic of Indonesia, Joko Widodo conveyed a program which became the main concern during his tenure as President. He named the program, Global Maritime Nexus (PMD) because Jokowi wanted to concentrate on cultivating and developing the marine wealth owned by Indonesia. It can be understood that the maritime culture that has long been inherent in Indonesian history and culture (Prasetyo et al., 2020). In this 2014 inaugural address, Joko Widodo mentioned the slogan adopted from Sanskrit verse "Jalasveva Jayamahe", which means "In the Ocean We Triumph" (TNI, 2020). Indonesia and China are countries that are also members of the G20 and APEC (Asia-Pacific Economy Coorperation) in the trade sector. Where these countries have established ChinaASEAN free trade zones to increase the value of exports and imports of the two countries. After the APEC CEO Summit held in Beijing in July 2014, several meetings were held by the Secretary General of the PRC, Xi Jinping, and the President of Indonesia, Joko Widodo. As a result of this bilateral meeting, the government delegation signed a Joint Statement on Comprehensive Strategic Partnerships between the Government of the Republic of Indonesia and the RRC Government. Following the partnership initiative, Indonesia has established stronger relations with China to improve its economy.

Indonesia has joined the AIIB (Asian Infrastructure Investment Bank), which is important for Indonesia to accelerate the development of its infrastructure, including the energy sector, transportation, agricultural and rural infrastructure telecommunications development, water and sanitation, environmental protection, logistics, urban development, and other productive sectors. China and Indonesia also agreed to build maritime cooperation, which is the key to this strategic 
cooperation. This is a new step to strengthen the previous maritime collaboration between the two countries. Both parties have made efforts to strengthen the mechanism of bilateral maritime cooperation in the fields of shipping safety, maritime security and maritime environment (Tinni, 2016). In these efforts it is necessary to develop a maritime-based economy in order to create public welfare. So far, Indonesia has lost a lot of economic income from the maritime or maritime sector. The World Maritime Axis idea is one of the efforts of the Jokowi government to improve connectivity and affordability between islands in Indonesia. The ultimate goal of this connectivity is to achieve equitable economic development and also to create maritime security in Indonesia (Laksamana, 2018).

In accordance with Law No. 32 of 2015 concerning Maritime Affairs, in article 14 it is stated that the central government and regional governments in accordance with their authority to conduct maritime processing for the greatest prosperity of the people through the utilization and exploitation of marine resources in the presence of the blue economy principle (Blue Economy). Blue Economy is a model in economic development that can integrate land and sea development by taking into account the carrying capacity of resources and the surrounding environment, because basically the potential of land and sea must be synergized in order to achieve Indonesia's power in the maritime sector. With Indonesia joining the OBOR project it is very much in line with Indonesia's ideals in cultivating the marine wealth owned by Indonesia. Infrastructure development and connectivity between regions through optimization of sea transportation to eliminate social and economic inequality, and to carry out various strategic national interests in government, security, trade, education, health, tourism, and also communication. Good connectivity between regions in Indonesia will be able to facilitate the movement of people, goods, services, and capital. The welfare gap that occurs due to low inter-island communication can create tension in various regions of Indonesia and prevent the creation of a just and prosperous Indonesian society. Therefore, the development of maritime infrastructure such as ports which serve as a node of trade activity and the provision of international standard transportation facilities, as well as facilities to support trade activities in the periphery of Indonesia, especially in Eastern Indonesia must be a concern. Bitung and Sorong should be developed into important hub ports in Eastern Indonesia, while Saumlaki needs to be strengthened given the high geostrategic value. Connectivity must be the backbone of Indonesian development, not Java sentris (Kementerian Koordinator Bidang Kemaritiman Republik Indonesia, 2017)

There are several journals and theses that discuss the World Maritime Axis that the author makes camparison. First, a journal entitled "Indonesia's Global Maritime Axis Doctrine: Security Concerns and Recommendations" written by Dewi Santoso and Fadhillah Nafisah in 2017. In this journal discusses the development of maritime security in Indonesia which pushed Indonesia to become a maritime force with considerable diplomatic influence. big for the world, and also the opportunities in it. Second, the study entitled "The Jokowi Maritime Axis Policy and the Synergy of Indonesian Ocean Economic and Security Strategy" written by M. Najeri Al Syahrin in 2018. In this study discusses the development of Indonesian sea power which requires strong economic capabilities. In this study also found that economics and security are two inseparable aspects and mutual support in the effort to realize the ideals of Indonesia as the World Maritime Axis.

This paper will discuss the prospects for Indonesia's public policy in the OBOR collaboration with China. Basically, in establishing cooperation with the concept of Business to 
Business in the OBOR project, Indonesia must consider several policies that need to be taken so that there is no consequence of loss in the future, either before or after the OBOR project has been completed. One issue that might arise is about Indonesia's sea security. Because the maritime region is the main artery of global economic and security interaction, making maritime security a very crucial issue for Indonesia. Understanding and efforts to realize the sea area as the centrality of the policy is expected to be able to realize the stability of maritime security and national interests, so that it has an impact on economic development and people's welfare (Nugraha et al., 2016).

The term policy is often used interchangeably with the term goals, programs, decisions or laws, provisions, proposals and grand designs (Syahrin, 2018). Policy is a reference in doing something. This reference can be simple or complex, can be general or specific. The National Policy issued by Jokowi at the East Asia Summit held on November 13, 2014 was a breakthrough that was very different from previous presidents. In the conference Jokowi expressed his wish to make Indonesia a Global Maritime Nexus.

What's interesting in this national policy is to develop the marine wealth that exists in Indonesia and want to lift Indonesian authority back to a country that is respected by other countries. This National Policy will always hold fast to what has been mandated by the constitution. In this case, Indonesia is very open to various kinds of cooperation with various countries, one of them with China with its OBOR project. Even so, Indonesia does not hesitate to act legally if a country steps on it. According to McRae, Indonesia's nationalistic foreign policy was more highlighted in the Joko Widodo era, especially with regard to maintaining its territorial maritime boundary (McRae, 2019).

Based on the above definition, public policy actually leads to the interests of the public, and takes into account existing values. So in that sense, a conclusion can be drawn if public policy is an action taken by a government which is oriented in the public interest. Public policy is a process that is carried out continuously, because it is the most important thing in the policy cycle. The policy cycle includes formulation, implementation, and policy evaluation (Gamage, 2016).

\section{Methods}

This research used descriptive qualitative method. By using a descriptive qualitative method, the author will explain the contents of this research based on the data that has been taken. This research takes data from various literature study sources. The various sources are international journals relating to the study of diplomacy and international cooperation between Indonesia and China. The author also takes data from the official website of the Indonesian Ministry of Foreign Affairs which provides information about foreign activities and also discussion about diplomatic relations between Indonesia and China, the Center for Strategic International Studies (CSIS) Indonesia, which focuses on the study of international issues and also several online news portals domestic and international reports about the OBOR project initiated by China. By taking data from various sources above, the writer will explain descriptively according to the data that authors took.

\section{Result and Discussion}

In this part, the author will divided into several sub-discussions. The sub-discussion will be drawn from the five pillars in the prospects of Indonesia becoming a world maritime nexus. 


\section{Priority in Developing Maritime Infrastructure and Connectivity in Indonesia}

Basically, the silk route that will be reactivated by China is one of the ways in which China can launch the economy of the bamboo curtain country. The design of OBOR is a strategic step for China to invite several countries to work together to build maritime infrastructure. In this case, Indonesia, which is a partner of the mega project, has the potential to get many sources of investment in the form of funding and maritime infrastructure development that comes from AIIB. Indonesia itself was offered by China to be able to get a golden opportunity, by getting $90 \%$ of a number of infrastructure projects later. With the lack of budget owned by Indonesia in moving towards the World Maritime Axis, it would seem difficult to be able to realize this dream without foreign investors. With the scheme through AIIB, Indonesia can get the funds needed from China. Sharing Budget, is one of the programs offered by AIIB in collaboration with several countries that have the same vision in the development of marine infrastructure. One of the projects offered by China for Indonesia is the construction of the Kuala Tanjung Port in North Sumatra and the Bitung Port in North Sulawesi. The construction of these two ports is in line with the government's vision to be able to level the economy in various regions in Indonesia, so that it is not too Java Centris (Sari, 2017). The problem of economic equality in Indonesia is indeed overlapping, many assume that indeed the economic development that exists in several regions in Indonesia has a very significant imbalance. Java Sentris, or all economic development is more focused on Java Island, this is what usually causes economic inequality.

If we look at the interests of China in the OBOR mega project, this is very much in line with Indonesia's vision of moving towards a global maritime axis. In this mega project, Indonesia can utilize to develop some of the maritime potential that exists in Indonesia. Indonesia, which is basically an archipelagic country, has a greater potential in marine wealth, including its marine charm in the eastern regions of Indonesia. But, in the process of maximizing the maritime potential, Indonesia needs to improve and also prepare a number of things, including the development of the availability of infrastructure and means of accommodation, consumption, transportation, sanitation, health, information center, security, guide services, and trade facilities. With this infrastructure development, the potential of the sea in eastern Indonesia can compete with the island of Java in general. Infrastructure development in the form of a port is one of the first steps in improving the facilities needed by Indonesia in this OBOR collaboration. Because the construction of a port which is concentrated in eastern Indonesia will make it easier and able to cut the logistics costs of domestic trade throughout Indonesia, with this basic needs can be met to the maximum.

Indonesia's interest in the OBOR project is indeed very much in line with the vision of becoming a Global Maritime Nexus country. This relates to three of the five pillars contained in the vision of the Global Maritime Nexus, namely maritime connectivity, maritime economy, and also maritime culture. The maritime infrastructure development is expected to be able to improve the connectivity of maritime routes throughout Indonesia, which in turn can have an impact on the Indonesian maritime economy. With this pathway, it is likely to further accelerate the growth of the Indonesian economy in the maritime field (Saha, 2016). 


\section{The Problems of Shipping Industry to Employment in Facing Competition OBOR Initiative}

The development of the OBOR project will affect several economic activities in Indonesia. With the ease of access to labor and also products from China that will enter Indonesia. This will be a challenge for Indonesia in responding to changes in economic activity. As we know, logistical problems between islands make Indonesia unable to compete with imported products, because imported products have lower logistics costs. In addition, even Indonesian products are not necessarily able to compete on a national scale, let alone having to compete with international products. This is caused by inter-island shipping costs which are considered very expensive. If this is left unchecked, Indonesian local products will likely be unable to compete with products originating from China. In this case, it can be concluded that if Indonesia is to succeed in cooperating with this OBOR project, Indonesia must be able to improve with all its local products in order to compete with imported products from China. The first thing that must be done by Indonesia is to be able to take full advantage of this OBOR project in order to increase the value of export trade through commodities that have high potential and have global competitiveness. Based on the Ministry of Trade, Indonesia's leading non-oil and gas export commodities include handcraft, fish and fish product derivatives, herbs, and leather products (Gindarsah \& Priamarizki 2015).

In addition to economic issues, the OBOR project will also affect employment. With the OBOR project, which acts as an investor, it cannot be denied if China will request easy access for Chinese workers to participate in making OBOR projects in Indonesia. This should be feared if the synchronization of workers from China and Indonesia does not run in a balanced way, or instead expands foreign workers from China, this will further increase the number of unemployed people in Indonesia because our workers cannot compete. Turnkey Project Management which is a Chinese investment model offered to Indonesia with a one package system, in the form of top management, funding with Preferential Buyer's Credit system, material and machinery, experts, up to methods directly imported by China (Mahesa, 2018).

\section{Maritime Diplomacy as a Way of Anticipation}

Illegal, Unreported and Unregulated (IUU) Fishing problems are the problems of the Indonesian sea which until now is still the government's concern in maintaining the wealth and ecosystems of Indonesia's marine life. From some naughty countries stealing Indonesia's marine wealth. Indonesia has made various efforts to overcome the problems of the Indonesian sea, one of the very controversial policies is sinking foreign ships that are active or even stealing fish illegally in Indonesian waters. In the period on October 2014 to December 2015, the Directorate General of Maritime and Fisheries Resources Supervision (PSDKP) of the Ministry of Maritime Affairs and Fisheries (KKP) had sunk 121 fishing vessels originating from neighboring countries, including China. Of the total 121 vessels that were submerged consisted of 39 Vietnamese ships, 12 ships from Malaysia, 36 ships from the Philippines, 21 ships from Thailand, 2 ships from Papua New Guinea, 1 ship from China and 10 ships from Indonesia (Diah, 2016). With the problem of theft occurring at sea in Indonesia, the country suffered a huge loss, amounting to 520 trillion rupiah in the period 2001 to 2003. Based on Skylight Monitoring System, this monitoring with 
remote sensing technology, SAR and optical. The system is able to identify ships directly and can predict illegal actions.

There are 1.647 foreign ships per day in April 2019. Meanwhile, in other months it tends to decrease. For example, 810 ships in May, 580 ships in June and 768 ships in July (CNN Indonesia, 2020).

Although the number of illegal vessels operating in Indonesia is not as large as that of several neighboring countries, it also needs to be watched out by Indonesia. Because, Indonesia and China had conflicts in Natuna waters, where the Chinese coast guard tried to thwart the efforts of the Indonesian maritime authorities to catch illegal fishermen. This case occurred in 2016, when KP Shark 11 wanted to catch KM Kway Fey 10078 which was a ship of illegal fishing from China on Natuna waters. However, the arrest process did not proceed smoothly because there was interference from the Chinese Coastguard, which intentionally crashed into KM Kway Fey 10078 (Arsana, 2016). With problems like this, maritime diplomacy is needed to maintain Indonesia's relations with friendly countries. Resolving these issues is very important in maintaining security and also the sovereignty of the Indonesian seas. In addition, maritime diplomacy is also very necessary to be implemented to maintain the integrity of the Unitary Republic of Indonesia. Maritime diplomacy will prioritize solving maritime security problems through cooperation. The maritime nexus policy also highlights Indonesian potential to become a maritime power in the regional sphree not only in terms of power but also in regional maritime diplomacy (Prasetya \& Estriani, 2018).

\section{Building Maritime Defense Force}

Indonesia and China basically clash with the Natuna Islands, even though the ownership of Natuna lau has been very clearly regulated in the United Nations Convention on the Law of Sea (UNCLOS) in 1982. But even so, the recognition of international law on Natuna sea ownership over Indonesia is still able to close illegal activities carried out by other countries. Some time ago, Indonesia carried out an update on the naming of the North Natuna Sea which is on the north side of Natuna Regency and directly borders with the South China Sea. However, China through its Ministry of Foreign Affairs sent an official message to the Indonesian Embassy in Beijing to express its refusal to change the name of the Natuna Sea. This official letter signaled China's strong rejection of the name change, but the Indonesian government did not want to withdraw the decision (Anggraini et al., 2018).

This is what made the government have special attention to the Natuna region in 2016. This effort was continued by Indonesia by building defense forces, including by building Apron and Sarpras Lanud R. Sajad, undertook the construction of the Natuna Island Penagi Jetty, the extension and widening of the Sebang Mawang Pier, Natuna Island, and also carried out the construction of TNI soldier accommodations in the form of barracks with the construction of Mako and Raider Battalions (Rohman, 2017). The development of maritime defense forces must also be supported by the presence of marine security patrol activities in the North Natuna Sea region.

In addition, considering that the Natuna Sea is one of the maritime trade routes with the Indonesian Archipelago Sea Channel (ALKI), namely ALKI I which is the maritime silk lane. This condition should be of more concern to Indonesia, because Indonesia is one of the territorial 
waters that has agreed on an international shipping zone or ALKI. If we look at the maritime silk route, ALKI I has the Malacca Strait which has a very strategic role, where the Malacca Strait connects the Indian Ocean with the South China Sea and the Pacific Ocean. In addition, the Malacca Strait is also a Choke Point in the Indian Ocean region because it becomes a dense shipping lane, where more than 70,000 ships transit annually. With the Choke Point, making Indonesia very strategic in shipping and international trade routes (Rohman, 2017).

\section{Maintenance and Management of Indonesian Marine Resources}

With the existence of this maritime silk route will be followed by an increase in ship traffic activities in the Straits of Malacca every year. This is also strengthened by the existence of OBOR cooperation which will increase demand in the trade of goods and services traded in the sea lane. With the increase in sea activity and also the demand for trade in goods and services between Indonesia and China, Indonesia must be prepared for the threat of damage to marine ecosystems.

In addition to massive marine activities, one of the problems that can be a threat to Indonesia's marine ecosystems is illegal fishing (Saha, 2016). The Ministry of Maritime Affairs and Fisheries, which has the responsibility for maintaining and managing Indonesia's marine resources, must be the frontline in the illegal fishing activities carried out by foreign vessels. In this case there needs to be special attention from the government to be able to maintain and maintain and process the wealth and potential of Indonesia's maritime (Hand, 2017). Therefore, there is a need for modernization of technology and there must also be sustainable funding. One of the very extreme policies of the Indonesian Ministry of Maritime Affairs and Fisheries was the sinking of ships during the Susi Pudjiastuti period when she was still a Minister. With a deft step, Susi dared to sink her lapa that was found to be doing illegal fishing in the Indonesian sea. The sinking policy of this ship was only the first carried out in the Susi Pudjiastuti period, in contrast to the previous Ministers. The sinking and shooting of the lasing case was carried out as a deterrent effect and was also one of the threat signals that had the function as a form of seriousness of Indonesia in maintaining and upholding its territorial sovereignty by carrying out the shooting and sinking of foreign ships.

Indonesia must maximize the Earthing of Marine Conservation as one of the steps the government can take in anticipating the negative impacts above. The government's Marine and Coastal Resources Management (MCRMP) program must be able to manage natural resources aimed at preserving and improving the welfare of the community in general. In addition, Indonesia must be able to limit the amount of demand for seafood to be exported to several countries. Because if there are no restrictions, it will be a disaster for the Indonesian sea, namely the Indonesian sea will be massive exploitation. This strategy seeks to organize national capabilities that are shown in combating illegal fishing activities so that Indonesia is expected to benefit not only from the economic side of marine empowerment but also to its maritime security interests (Paskarina, 2016).

\section{Conclusion}

There are several national policies that can be implemented by Indonesia to strengthen its position as an actor in OBOR. What Indonesia needs to do is always provide escort to Indonesia's national interests in the OBOR project. Indonesia must always refer to the five pillars of the World 
Maritime Nexus, in order to provide absolute benefits for Indonesia. In addition, all elements of the Indonesian government must also take a role in the success of this collaboration. Some crucial Indonesian institutions such as the Ministry of Trade must be able to take advantage of this collaboration as much as possible, in order to be able to market Indonesian products to the full. Next is the Ministry of Manpower which must be strict in monitoring the number of foreign workers that may be brought in to succeed the OBOR project, lest the absorption of Indonesian workers is less than foreign workers. In addition, the Ministry of Defense, the Ministry of Foreign Affairs and also the TNI must unite to maintain the sovereignty of the Republic of Indonesia. There must be no conflict in the Indonesian Sea that will only harm Indonesia. With the cooperation of all institutions and elements of the Indonesian government, it is not impossible if Indonesia will become the Global Maritime Nexus.

\section{References}

Anggraini, Dian, Kusumawardhana, Indra \& Ramadhan, Iqbal. (2018). "The Implication of Indonesia's IUU Fishing Policy in Natuna Territorial Waters towards South China Sea Geopolitics", Jurnal Hubungan Internasional (2018): Vol. 7, No. 2, https://doi.org/10.18196/hi.72130

Arsana, Anadi. (2016). "Menyingkap Misteri Laut Tiongkok Selatan”, a Madeandi's life blog. https://madeandi.com/2016/06/26/menyingkap-misteri-laut-tiongkok-selatan/ (accessed, August 4, 2020)

CNN Indonesia. (2020). "Jumlah Kapal Asing di Natuna Tembus Seribu per Hari”. Link : https://www.cnnindonesia.com/ekonomi/20200105102943-92-462510/jumlah-kapalasing-di-natuna-tembus-seribu-per-hari (accessed, March 10, 2021)

Cai, Peter. (2017). “Understanding China's Belt and Road Initiative, Lowy Institute For International Policy, hal.

2: https://www.lowyinstitute.org/sites/default/files/documents/Understanding $\% 20$ China $\% \mathrm{E} 2 \% 80 \% 99 \mathrm{~s} \% 20 \mathrm{Belt}^{2} \% 20 \mathrm{and} \% 20 \mathrm{Road} \% 20$ Initiative WEB 1.pdf (accessed August 20 , 2020).

Chen, Jonathan. (2014). “"New Perspectives on Indonesia: Understanding Australia's Closest Asian Neigbbour”. Perth: Perth USAsia Centre.(2014). https://perthusasia.edu.au/PerthUSAsia/media/Perth USAsia/Publications/New-

Perspectives-on-Indonesia-Understanding-Australias-Closest-Neighbour.pdf (accessed, August 21, 2020)

Diah, Sakina. (2016). “57 Pelaku Illegal Fishing” Siap ditenggelamkan Tahun ini”.: https://money.kompas.com/read/2016/01/06/124559126/57.Kapal.Pelaku.Illegal.Fishin g.Siap.Ditenggelamkan.Tahun.Ini (accessed, August 16, 2020)

Gamage, Rajni Nayanthara. (2016). "Blue Economy in Southeast Asia: Oceans as The New Frontier of Economic Development", Maritime Affairs: Journal of the National Maritime Foundation of India (2016): pp. 1-15, http://dx.doi.org/10.1080/09733159.2016.1244361

Gindarsah, Iis \& Priamarizki. (2015). "Indonesia's Maritime Doctrine and Security Concerns". https://www.jstor.org/stable/resrep05869?seq=1\#metadata info tab contents (accessed, August 20, 2020). 
Hand, Marcus. (2017). “China’s One Belt-One Road Policy 'Very Positive’ for Shipping”, Sea Trade Maritime: https://www.seatrade-maritime.com/asia/chinas-one-belt-one-road-policy-verypositive-shipping (accessed, September 1, 2020)

Kementerian Koordinator Bidang Kemaritiman Republik Indonesia, "Kebijakan Kelautan" (2017):

https://maritim.go.id/konten/unggahan/2017/07/Kebijakan Kelautan Indonesia Indo vers.pdf (accessed, September 20, 2020)

Khurana, Gurpreet. (2015). "China, India and "Maritime Silk Road": Seeking a Confluence", Maritime Affairs: Journal of The National Maritime Foundation of India (2015): Vol. 11 No. 1 Summer, pp. 19-29, http://dx.doi.org/10.1080/09733159.2015.1025536

Laksamana, Evan, Gindarsih, Iis \& Mintong, Andre. (2018). "Menerjemahkan Visi Poros Maritim Global ke Diplomasi Pertahanan Maritim Dalam Kebijakan Luar Negeri Indonesia di Era Jokowi", Jakarta Centre for Strategic and International Studies: https://www.csis.or.id/uploaded file/publications/menerjemahkan visi poros maritim global ke dalam kerangka diplomasi pertahanan maritim dalam kebijakan luar negeri indonesia di era jokowi.pdf (accessed, August 23, 2020)

Lovina, H. R., Jiajia, G., \& Chen, H. (2014). Review of "The Chinese Belt and Road Initiative": Indonesia-China Cooperation and Future Opportunities for Indonesia's Port Cities Development. Journal of Regional and City Planning, 28, 163.

Mahesa, D.J. (2018). "Solusi Mengatasi Membanjirnya Tenaga Kerja China di Indonesia", Law Justice (2018): https://www.law-justice.co/artikel/43544/solusi-mengatasi-membanjirnyatenaga-kerja-china-di-indonesia/ (accessed, August 15, 2020)

Mwatela, Ziro, Raphael \& Changfeng, Zhao. (2016). "'Africa in China's One Belt One Road Initiative: A Critical Analysis". IOSR Journal of Humanities and Social Science (IOSR-JHSS): 21, $2 \operatorname{Ver} 1$, pp. 11.

McRae, Dave. (2019). “Indonesia’s South China Sea Diplomacy: A Foreign Policy Illeberal Turn?”, Journal of Contemporary Asia: Vol. 29, https://doi.org/10.1080/00472336.2019.1601240

Nugraha, Ari Muhammad \& Sudirman, Arifin. (2016). "“Maritime Diplomacy Sebagai Strategi Pembangunan Keamanan Maritim Indonesia”, Jurnal Wacana Politik: Vol. 1, No. 2, pp. 175 182

Prasetya, Dion, Haffsari, Puspa \& Estiani, Heavy. (2020). "Identity Matters: Indonesia’s Approach towards Territorial Disputes in South-east Asia", Maritime Affairs: Journal of The National Maritime Foundation of India: https:// doi.org/10.1080/09733159.2020.1836775

Prasetya, Dion \& Estiani, Heavy. (2018). "Diplomasi Maritim Indonesia dalam Indian Ocean Rim Association (IORA): Peluang dan Tantangan”, Insigna: Journal of International Relations: Vol. 5, No. 2, pp. 96-108

Paskarina, Caroline. (2016). "Wacana Negara Maritim dan Reimajinasi Nasionalisme Indonesia", Jurnal Wacana Politik: Vol. 1, No. 1, pp. 1-8

Rohman, "Indonesia Bangun Sarana dan Prasarana Pertahanan di Natuna", Jakarta Greater (2017): https://jakartagreater.com/indonesia-bangun-sarana-dan-prasarana-pertahanan-di-natuna/ (accessed, September 3, 2020). 
Copyright (C) 2021, Riko R. Setiawan, Muhammad Kamil This is an open access article under the CC-BY-SA license
ISSN 2088-8090 (Print) ISSN 2597-6648 (Online) Sospol: Jurnal Sosial Politik Vol 7 No 1 (2021), pp.77-88

Saha, Premesha. (2016). "“'Indonesia's Potential as a Maritime Power”, Maritime Affairs: Journal of The National Maritime Foundation of India (2016): Vol. 12, No. 2, pp. 28-41, http://dx.doi.org/10.1080/09733159.2016.1232951

Sari, Rafika. (2017). "Prospek Jalan Sutra Modern Bagi Perekonomian Indonesia”, Majalab Ekonomi dan Kebijakan Publik: Vol. IX, No. 10, pp. 13-16,

Singh, Ghosal, Antara. (2016). "China's Soft Power Projection Across the Oceans". Maritime Affairs: Journal of The National Maritime Foundation of India (2016): Vol. 12, No. 1, pp. 25-37, http://dx.doi.org/10.1080/09733159.2016.1181396

Syahrin, Najeri. (2018). "Kebijakan Poros Maritim Jokowi dan Sinergitas Strategi Ekonomi dan Keamanan Laut Indonesi", Indonesia Perspective, Vol. 3, No. 1, pp. 1-17

Tentara Nasional Indonesia Angkatan Laut, "Doktrin TNI Angkatan Laut Jalesveva-Jayamahe,", https://www.tnial.mil.id/doktrin/ (accessed, September 1, 2020)

Tinni, Khadijah. (2016). "Kepentingan Indonesia Bergabung Dalam Asian Infrastructure Investment Bank (AIIB). Universitas Muhammadiyah Makassar. http://repository.umy.ac.id/bitstream/handle/123456789/7646/Naskah\%20Publikasi.pdf ?sequence $=1$ (accessed, September 21, 2020)

Yunling, Zhan. (2015) “One Belt One Road: a Chinese View”. Global Asia. Vol. 10. No. 3. https://www.globalasia.org/v10no3/cover/one-belt-one-road-a-chinese-view zhangyunling (accessed August 20, 2020) 